\title{
ANALISIS KINERJA PARAMETER THROUGHPUT DAN DELAY AKSES INETRNET DI SMK KARYAGUNA JAKARTA SELATAN Vanny Andini' ${ }^{1}$, Lipur Sugiyanta ${ }^{2}$, Bachren Zaini $^{3}$
}

${ }^{1}$ Mahasiswa Prodi PendidikanTeknik Informatika dan Komputer, Teknik Elektro, FT - UNJ

${ }^{2,3}$ Dosen Prodi Pendidikan Teknik Informatika dan Komputer, Teknik Elektro, FT - UNJ

${ }^{1}$ vannyandini96@gmail.com, ${ }^{2}$ lipurs@unj.ac.id, ${ }^{3}$ bachrenz@unj.ac.id

\begin{abstract}
Abstrak
Penelitian ini dilakukan untuk menganalisa kinerja parameter throughput dan delay akses internet di SMK Karyaguna menggunakan piranti lunak Axence Net Tools Pro 5.0. Penelitian ini menggunakan metode penelitian rekayasa teknik, tahap implementasi hanya sampai pada tahapan pengukuran meliputi throughput dan delay dengan melakukan monitoring streaming dari laptop client ke server Berdasarkan hasil akhir dari analisis dapat simpulkan bahwa kinerja parameter throughput dan delay pada jaringan SMK Karyaguna masih jauh dari kata layak karena dipengaruhi oleh ke 2 parameter tersebut yaitu throughput dan delay. Throughput pada titik akses ruang guru dan titik akses ruang TKJ untuk perangkat monitor server www.yahoo.com didapatkan 5.77872\%; www.detik.com didapatkan 33.0752\%; www.facebook.com didapatkan 14.1951\%. Delay pada www.yahoo.com didapati rata-rata delay terbesar yaitu pada pengukuran pada ruang TKJ sebesar 435 ms, delay ini menurut versi TIPHON termasuk kategori delay jelek karena delay $>150$ ms, untuk pengukuran pada ruang guru didapati rata-rata delay sebesar $121 \mathrm{~ms}$ mendapatkan predikat sedang karena delay berkisar 100 sampai dengan 150. Setelah itu untuk perangkat server www.detik.com pada titik akses guru mendapatkan delay 118 ms mendapatkan predikat sedang dan pada titik akses ruang TKJ delay sebesar 25 ms yang berarti bagus karena delay berkisar 50 sampai dengan 100. Pada perangkat www.facebook.com, workstation ruang guru mendapatkan delay $142 \mathrm{~ms}$ yang berarti sedang karena berkisar dari 100 sampai dengan 150ms. Lalu pada workstation ruang TKJ mendapatkan delay 59 yang berarti bagus.
\end{abstract}

Kata Kunci : Throughput, Delay, Bandwith, Akses Internet

\section{Pembahasan}

Sebagian besar sekolah di kota-kota besar di Indonesia sudah memiliki komputer yang terhubung dengan internet, yang berfungsi untuk administrasi sekolah maupun dalam proses pembelajaran, untuk mempermudah proses komunikasi dan pertukaran data maka setiap komputer harus terhubung ke sebuah jaringan baik jaringan kabel ataupun nirkabel.

Menurut Sugiyanta \& Sukardjo (2018), populasi pengguna internet di Indonesia mencapai 83,7 juta orang atau nomor 6 di dunia, potensi pemanfaatan smartphone dalam pembelajaran sekolah menengah di Indonesia masih minim. Internet sangat diperlukan di bidang pendidikan. SMK Karyaguna Jakarta Selatan menggunakan internet sebagai penunjang sarana dan prasarana bagi semua masyarakat yang ada di lingkungan sekolah.

Pendidikan di masa depan lebih mungkin dalam bentuk pendidikan dan pelatihan dengan menerapkan aplikasi jarak jauh, Sugiyanta \& Sukardjo (2018). Maka satu hal yang penting adalah memberikan kualitas layanan yang baik bagi pengguna jaringan tersebut. Dalam menghubungkan jaringan internet menggunakan wifi di SMK Karyaguna, banyak sekali user yang mengeluh karena ketika ingin mengakses internet sebagai bahan pembelajaran di kelas, jaringan wifi sering kali tidak dapat diakses, hanya yang pertama kali login yang dapat mengakses wifi tersebut selebihnya tidak dapat terhubungi. Jika sudah terhubung ke wifi maka pada saat jam sekolah aksesnya akan lambat dan kualitas jaringan akan menurun.

Suatu kualitas jaringan yang baik maka kinerja jaringan harus berada pada kondisi yang baik. Kinerja suatu jaringan itu sendiri dapat dipengaruhi oleh beberapa masalah yang dapat memberikan dampak ketidakstabilan yang cukup besar kepada kinerja suatu jaringan yang berpengaruh pada kualitas pelayanan dari jaringan internet itu sendiri yang terdiri dari throughput dan delay. Kapasitas Access point di SMK Karyaguna tidak dapat menampung sesuai dengan kebutuhan jumlah user sehingga akses internetnya cenderung lambat, yang menyebabkan parameter throughput dan delay kinerja jaringan wifi di SMK Karyaguna belum baik. Besar bandwidth di SMK Karyaguna adalah 50 Mbps.

\section{Kerangka Teoritik}

2.1. Jaringan /wireless

Menurut Fahlevi (2017: 3), Jaringan nirkabel /wireless merupakan jaringan yang tidak menggunakan kabel dalam hal komunikasi maupun data. Teknologi wireless ini memanfaatkan 
frekuensi tinggi untuk menghantarkan sebuah data, maka kerentanan terhadap keamanan juga lebih tinggi dibanding teknologi lainnya. Dengan adanya teknologi wireless seseorang dapat beraktifitas dimanapun untuk melakukan komunikasi data maupun suara tanpa kabel.

\subsection{Throughput}

Throughput adalah laju data yang dikirim melalui jaringan, biasanya diekspresikan dalam satuan bits per second (bps) atau byte per second (Bps). Throughput merujuk pada besar data yang dibawa oleh trafik jaringan. Throughput diukur dengan cara menghitung bytes yang dikirim selama rentang waktu tertentu. Besarnya selang waktu pengukuran dapat mempengaruhi hasil gambaran perilaku jaringan. Selang waktu yang terlalu besar dapat berakibat menghilangkan gambaran perilaku jaringan yang terjadi, sedangkan selang waktu pengukuran yang terlalu kecil memberikan koleksi kelajuan data yang lebih banyak dan dapat mengubah gambaran perilaku jaringan yang sebenarnya, (Brownlee N., Loosley C, 2001: 8).

\subsection{Delay (Latency)}

Delay adalah waktu yang dibutuhkan data untuk menempuh jarak dari asal hingga ke tujuan. Delay dapat dipengaruhi oleh jarak, media fisik, kongesti atau juga waktu proses yang lama. Delay merupakan lamanya waktu yang dibutuhkan oleh data atau informasi untuk sampai ke tempat tujuan data atau informasi tersebut dikirim. Delay pada suatu jaringan akan menentukan langkah apa yang akan kita ambil ketika kita memanajemen suatu jaringan. (Forouzan, 2007: 36)

\section{Metodologi Penelitian}

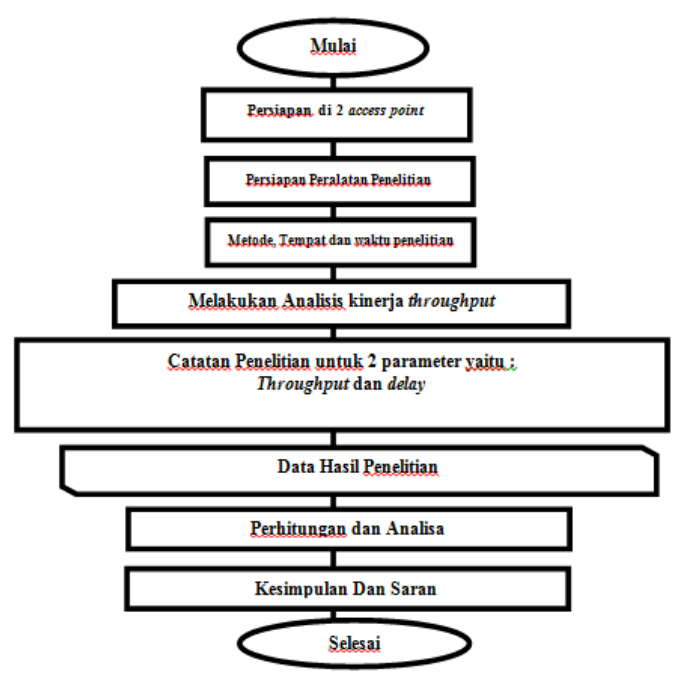

Metode penelitian yang digunakan oleh peneliti adalah metode rekayasa teknik. Tujuan dari penelitian rekayasa teknik adalah untuk menganalisis masalah berdasarkan kumpulan konsep data dan alat-alat bantu (tools) setelah sistem yang kompleks. Dalam menganalisis elemenelemen setelah sistem diterapkan dengan pengorganisasian seperti melakukan perbandingan atau evaluasi dalam menentukan prosedur teknikal dalam menghadapi masalah.

\subsection{Pengumpulan Data}

Pada tahap ini dilakukan perencanaan mengenai pengukuran kinerja parameter throughput yang terdiri dari throughput dan delay dari node pengirim ke node penerima atau dari ujung ke ujung (end to end) dengan menggunakan alat bantu monitoring Axcence Net Tools Pro 5.0. Pengukuran dilakukan pada bulan Juli 2018 pada jaringan access point yang mengalami keluhan. Waktu pengukuran berkisar antara jam 08.00 sampai dengan selesai.

\subsection{Teknik Analisis Data}

Pada tahap ini dilakukan pengukuran terhadap kinerja parameter throughput dan delay pada proses transmisi data dari pengirim ke perangkat penerima (destination) atau dari ujung ke ujung (end to end) dengan menggunakan monitoring software Axence Net Tools Pro 5.0. Pengukuran dilakukan pada beberapa access point yang mendapatkan keluhan dari user. access point tersebut adalah beberapa jaringan hotspot yang meliputi ruang guru dan ruang TKJ sebagai penerima paket data (destination). Penelitian dilakukan dengan interval waktu dari jam 08.00 sampai dengan selesai.

\section{Hasil dan Analisis}

Perhitungan throughput yang menggunakan user pada access point ruang guru dan ruang TKJ untuk perangkat monitor server www.yahoo.com didapatkan throughput terkecil yaitu sebesar 347435 bps pada perangkat ruang TKJ dan jika dibandingkan dengan bandwidth maka didapat presentase $3.47435 \%$. Untuk perangkat monitor server www.detik.com didapatkan throughput terkecil yaitu sebesar 1179267 bps pada perangkat ruang TKJ jika dibandingkan dengan bandwidth maka didapatkan presentase $11.79267 \%$. sedangkan pada perangkat monitor server www.facebook.com throughput terkecil sebesar 444963 bps dibandingkan dengan bandwidth presentasenya $4.44963 \%$.

\begin{tabular}{|c|c|c|c|c|c|}
\hline No & $\begin{array}{c}\text { Nama } \\
\text { Perangkat }\end{array}$ & Server Tujuan & $\begin{array}{c}\text { Bandwith } \\
\text { tersedia }\end{array}$ & $\begin{array}{c}\text { Average } \\
\text { Throughput }\end{array}$ & $\begin{array}{c}\text { Presentase } \\
(\%)\end{array}$ \\
\hline 1 & Ruang Guru & www.detik.com & 10000024 & 1179267 & 11.7926 \\
\hline & & www.facebook.com & 10000024 & 444963 & 4.4496 \\
\hline & & www.yahoo.com & 10000024 & 347435 & 3.4743 \\
\hline 2 & Ruang TKJ & www.detik.com & 10000024 & 1853460 & 18.5345 \\
\hline & & www.facebook.com & 10000024 & 647345 & 6.4734 \\
\hline & & www.yahoo.com & 10000024 & 577024 & 5.7702 \\
\hline
\end{tabular}

Tabel 4.1 Hasil analisis throughput

Hasil pengukuran delay yang menggunakan user untuk tiap-tiap perangkat server www.facebook.com didapatkan rata-rata delay 
terbesar yaitu pada pengukuran pada ruang guru sebesar $123 \mathrm{~ms}$, delay ini menurut versi TIPHON termasuk kategori delay sangat bagus berkisar $<150$, untuk pengukuran perangkat server www.yahoo.com access point ruang guru mendapatkan delay $95 \mathrm{~ms}$ yang berarti sangat bagus karena berkisar $<150$ dan pada ruang TKJ didapati rata-rata delay sebesar $67 \mathrm{~ms}$ mendapatkan predikat sangat bagus karena delay berkisar $<150$. Setelah itu untuk perangkat server www.detik.com pada Access point guru mendapatkan delay $99 \mathrm{~ms}$ mendapatkan predikat sangat bagus dan pada ruang TKJ delay sebesar 57 ms yang berarti sangat bagus karena delay berkisar <150. Pada perangkat www.facebook.com, Access point ruang guru mendapatkan delay $123 \mathrm{~ms}$ yang berarti sangat bagus karena berkisar <150. Lalu pada Access point ruang TKJ mendapatkan delay 67 yang berarti sangat bagus.

\begin{tabular}{|c|l|c|c|}
\hline No & Perangkat Pengukuran & $\begin{array}{c}\text { Rata-rata } \\
\text { Delay (ms) }\end{array}$ & TIPHON \\
\hline 1 & \multicolumn{1}{|c|}{ Ruang Guru } & & \\
\hline \multirow{2}{*}{2} & www.detik.com & 99 & Sangat Bagus \\
& www.facebook.com & 123 & Sangat Bagus \\
& www.yahoo.com & 95 & Sangat Bagus \\
\hline \multirow{2}{*}{ Ruang TKJ } & & \\
& www.detik.com & 57 & Sangat Bagus \\
& www.facebook.com & 67 & Sangat Bagus \\
& www.yahoo.com & 67 & Sangat Bagus \\
\hline
\end{tabular}

Tabel 4.2 Hasil analisis delay

\section{Kesimpulan dan Saran}

\subsection{Kesimpulan}

Kesimpulan dari hasil pengukuran dan pembahasan di atas terdapat beberapa faktor yang dapat mempengaruhi kualitas jaringan nirkabel pada jaringan SMK Karyaguna yaitu sebagai berikut.

1. Menganalisis throughput dengan cara menggunakan software Axence Nettools 5. Cara melakukan pengukuran throughput yaitu pilih menu bandwidth, ketikan alamat IP address atau alamat server tujuan yaitu server gateway dan server www.yahoo.co.id, maka akan tampil hasil dari pengukuran berupa bandwith maximum, bandwith minimum, dan average bandwith. Cara melakukan pengukuran delay yaitu pilih menu netwatch, ketikan alamat IP address atau alamat server tujuan yaitu server gateway dan server www.yahoo.com maka akan tampil hasil dari pengukuran berupa data delay yang terdiri dari last, minimum, maximum, average. Setelah mendapatkan hasil pengukuran data dicari rata-rata kemudian di analisis, untuk throughput dan delay menggunakan rumus presentase average : bandwidth $\times 100$.

2. Berdasarkan hasil akhir dari analisis dapat simpulkan bahwa kinerja parameter throughput pada jaringan SMK Karyaguna masih jauh dari kata layak karena dipengaruhi oleh ke 2 parameter tersebut yaitu throughput dan delay.
3. Kualitas layanan di SMK Karyaguna juga masih buruk dikarenakan kapasitas access point yang tidak dapat menampung jumlah user dan juga masih memiliki sistem pemeliharaan server yang buruk.

4. Pada saat akses internet, traffic pada jaringan yang sedang digunakan oleh jumlah user yang banyak maka akan terjadi persaingan dalam penggunaan akses jaringan sehingga menyebabkan akses internet yang lambat. Sedangkan, pada jaringan yang sedang digunakan oleh jumlah user yang sedikit traffic pada jaringan internet tidak melakukan persaingan sehingga akses internet menjadi cepat.

\subsection{Saran}

1. Untuk pengembangan dalam skripsi ini perlu dilakukan penelitian lebih lanjut, seperti mengimplementasikan hasil penelitian throughput dan delay sebagai acuan untuk akses internet yang lebih memadai.

2. Perlu adanya pergantian access point yang lebih memadai kapasitasnya sesuai dengan jumlah user yang berada di SMK Karyaguna.

\section{Daftar Pustaka :}

Andrew S. Tanenbaum. (2001). Computer Networks. Amsterdam.

Astuti. (2015). Teletrafik Sistem Berbagai Pada Aliran Internet. Proceedings Seminar RETII. Yogyakarta. Jurnal Teknologi, 9:124-131

Bambang Sugiantoro. (2017). Analisis Quality Of Service Jaringan Wireless Sukanet Wifi Di Fakultas Sains Dan Teknologi UIN Sunan Kalijaga. Yogyakarta. Jurnal Teknik Informatika, 10:191-201

Bates. (1995). Oil rheology and journal bearing performance. America

Behrouz A. Forouzan. (2007). Data Communication and Networking. Avenue Of The Americas. New York: NY10020.

Brownlee N Loosley. (2001). Fundamentals of Internet Measurement. San Mateo:CA 94403

Choerul Aldi Wibowo. (2016). Jaringan Wireless. Depok:Universitas Gunadarma. Jurnal Jaringan Wireless, 10:150-185

[Depdiknas] Departemen Pendidikan Nasional. (2008). Kamus Besar Bahasa

Indonesia. Jakarta: Balai Pustaka.

[Depdiknas] Departemen Pendidikan Nasional. (2000). Kamus Akutansi. Jakarta: Balai Pustaka. 
[Depdiknas] Departemen Pendidikan Nasional. (2008). Kamus Pusat Pembinaan dan Pengembangan Bahasa. Jakarta: Balai Pustaka.

[FT] Fakultas Teknik. 2009. Pedoman Penulisan Skripsi. Jakarta: Fakultas Teknik, Universitas Negeri Jakarta.

Kamarullah. (2009). Penerapan Metode Quality of Service pada Jaringan yang Padat. Palembang: Unversitas Sriwijaya. e-journal Teknik Elektro dan Komputer (2014), ISSN: 2301-8402

Muhammad Faisal Fahlevi. (2017). Analisis Dan Perancangan Jaringan Nirkabel (Wlan) Studi Kasus Di Jogjakarta Montessori School Menggunakan Metodologi PPDIOO. Yogyakarta.

Rahardjo, Budi. (2005). Teknik Pemrograman Pascal. Bandung:Informatika

Santosa, B, 2004, Management Bandwith Internet dan Intranet. Medan.

Sugiyanta Lipur and Soekardjo .M, "The Role of Blended Mobile Learning in Algebra." International Conference Asosiasi Pendidikan Teknologi dan Kejuruan Indonesia.

Sugiyanta Lipur and Soekardjo .M, “Adjusted Framework of M-Learning in Blended Learning System for Mathematics Study Field of Junior High School Level VII." International Conference Asosiasi Pendidikan Teknologi dan Kejuruan Indonesia.

Suhervan. (2010). Analisis Kinerja Teknologi Jaringan Wireless Pada Frekuensi 2.4 Ghz Dalam Kondisi Ruangan Tertentu. Yogyakarta.

Terplan. (1987). Network Management and Control. New York

Tiphon. (1999). Telecommunication and Internet Protocol Harmonization Over Network.

Youdant. (2011). Analisis Kinerja Sistem. Jakarta 